\title{
2021 Handbook of Florida Water Regulation: Florida Everglades Forever Act ${ }^{1}$
}

\author{
Michael T. Olexa, Tatiana Borisova, and Jana Caracciolo²
}

\section{Preface}

This handbook is designed to provide an accurate, current, and authoritative summary of the principal federal and state (Florida) laws that directly or indirectly relate to agriculture. This handbook provides a basic overview of the many rights and responsibilities that farmers and farmland owners have under both federal and state laws as well as the appropriate contact information to obtain more detailed information. However, the reader should be aware that because the laws, administrative rulings, and court decisions on which this handbook is based are subject to constant revision, portions of this publication could become outdated at any time. Several details of cited laws are also left out due to space limitations. This handbook is provided as an educational text for those interested in water use and water resource issues in Florida.

This handbook is distributed with the understanding that the authors are not engaged in rendering legal or other professional advice, and the information contained herein should not be regarded as a substitute for professional advice. This handbook is not all inclusive in providing information to achieve compliance with the federal and state laws and regulations governing water protection. For these reasons, the use of these materials by any person constitutes an agreement to hold harmless the authors, the UF/IFAS Center for Agricultural and Natural Resource Law, and UF/IFAS Extension for any liability claims, damages, or expenses that may be incurred by any person as a result of reference to or reliance on the information contained in this handbook. Note: UF/IFAS is the acronym for University of Florida, Institute of Food and Agricultural Sciences.

\section{FEFA Overview}

The Florida Everglades Forever Act (FEFA) was passed in 1994. The primary goals of FEFA are to improve water quality by reducing the level of phosphorus that enters the Everglades ecosystem, to increase the quantity of water in the Everglades by restoring the hydrology of the ecosystem, and to restore and protect the native plants and animals of the Everglades by stemming the invasion of exotic species of plants and animals into the ecosystem. The secondary goals of FEFA include water resource development and supply, better public access, public land management and maintenance, and acquisition of conservation easements.

FEFA outlines the state government's commitment to restore the Everglades ecosystem in cooperation with the federal government's multi-billion-dollar, multi-decade Comprehensive Everglades Restoration Program (CERP, https://evergladesrestoration.gov/). FEFA also sets the mechanism for the state to finance the construction of stormwater treatment areas for water entering the Everglades (to ultimately improve water quality in the

1. This document is FE609, one of a series of the Food and Resource Economics Department, UF/IFAS Extension. Original publication date October 1998. Revised June 2017 and April 2021. Visit the EDIS website at https://edis.ifas.ufl.edu for the currently supported version of this publication.

2. Michael T. Olexa, professor, Food and Resource Economics Department, and director, UF/IFAS Center for Agricultural and Natural Resource Law; Tatiana Borisova, associate professor, Food and Resource Economics Department; and Jana Caracciolo, student, Levin College of Law; UF/IFAS Extension, Gainesville, FL 32611.

The Institute of Food and Agricultural Sciences (IFAS) is an Equal Opportunity Institution authorized to provide research, educational information and other services

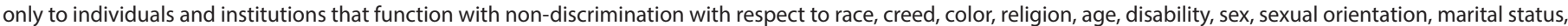

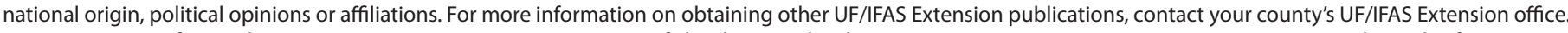
U.S. Department of Agriculture, UF/IFAS Extension Service, University of Florida, IFAS, Florida A \& M University Cooperative Extension Program, and Boards of County Commissioners Cooperating. Nick T. Place, dean for UF/IFAS Extension. 
Everglades). In addition to the stormwater treatment areas, best management practices are discussed as a tool to address phosphorus pollution loading to the Everglades, particularly, from agricultural areas. Finally, FEFA establishes the numeric criteria for water quality in the Everglades (i.e., 10 parts per billion phosphorus concentration).

\section{Who enforces FEFA?}

Under FEFA, both the Florida Department of Environmental Protection (FDEP) and the South Florida Water Management District (SFWMD) are given enforcement power and duties on such issues as:

- the Everglades Construction Project (that includes stormwater treatment areas, and other initiatives)

- water supply improvement and restoration

- the Everglades research and monitoring program

- evaluation of water quality standards

- implementation of BMPs against phosphorus runoff in the Everglades Agricultural Area

- monitoring and controlling exotic species

- assessing and collecting taxes and special assessments

Major goals are to decrease the levels of phosphorus in the Everglades to acceptable levels and to improve the overall health of the Everglades Ecosystem and surrounding vicinities.

\section{What are the duties of FDEP and SFWMD under FEFA?}

Everglades construction project: Under FEFA, SFWMD is charged with implementing the Everglades Construction Project (ECP), whereby the state or SFWMD purchases land to build stormwater treatment facilities to improve the quality of waters coming from the Everglades Agricultural Area. Public lands are also included in the Everglades Construction Project with the goal to treat and improve the quality of waters not coming from Everglades Agricultural Area.

There is a limit on the tax rate that SFWMD can set to fund the Everglades Construction Project. Under FEFA, SFWMD cannot levy ad valorem taxes in excess of 0.1 mill within the Okeechobee Basin (which means no more than 10 cents for every $\$ 1,000$ of taxable property value). SFWMD must obtain a National Pollutant Discharge Elimination System Watershed Permit to build stormwater treatment facilities to participate in the Everglades Construction Project.
Once stormwater facilities are built, SFWMD must allow these areas to be used by the public for recreation unless the SFWMD governing board shows that recreational use of stormwater treatment areas is incompatible with the restoration goal of the Everglades Construction Project.

Improvement and restoration of the Everglades water supply: SFWMD uses stormwater treatment areas to increase the quantity of water in the Everglades ecosystem. SFWMD must coordinate its water supply program with the federal government and, along with FDEP, push for amendments to the federal restoration program if needed.

Research and monitoring of the Everglades: FDEP and SFWMD head a research and monitoring program to generate water quality data for the Everglades and to evaluate the effectiveness of best management practices (BMPs) and stormwater treatment areas in reducing the levels of phosphorus in the Everglades and Everglades Agricultural Area. FDEP and SFWMD use the research and monitoring results to evaluate water quality standards and to implement Total Maximum Daily Load (TMDL) plans and BMPs in the Everglades and Everglades Agricultural Area. Beginning March 1, 2006, annual reports summarizing the data and findings of the research and monitoring program must be issued by FDEP and SFWMD.

Exotic species: In addition to water quality, the monitoring and controlling of exotic species is the exclusive duty of SFWMD. FEFA requires that SFWMD establish a biological monitoring network throughout the Everglades and perform a survey of exotic species at least every two years. SFWMD is also required to coordinate with federal, state, and/or other governmental entities the control of exotic species in the Everglades and Everglades Agricultural Area.

Assessing and collecting taxes and special assessments: It is also the exclusive duty of SFWMD to assess and collect agricultural privilege taxes on agricultural land in the Everglades Agricultural Area and C-139 basin (the name of the actual basin) for the privilege of using these lands for agricultural purposes. SFWMD may also levy a special assessment on all areas that benefit from stormwater treatment areas. As mentioned above, SFWMD cannot levy ad valorem taxes in excess of 0.1 mill within the Okeechobee Basin for the purposes of the design, construction, and acquisition of the Everglades Construction Project. All money generated by these taxes and special assessment will be used to fund SFWMD's enforcement and implementation of FEFA. 
For more information on FEFA, including state acquisition of land, and the criteria for the agricultural privilege taxes on agricultural land in Everglades Agricultural Area and C-139 basin, contact FDEP or SFWMD.

Additional information about the Everglades restoration programs can be found at the FDEP website (http://www. dep.state.fl.us/everglades/default.htm).

For more information about the National Pollutant Discharge Elimination System Watershed Permit for the Everglades Construction Project Stormwater Treatment Area, visit the FDEP website (http://www.dep.state.fl.us/ everglades/ecp_sta.htm).

\section{Sources}

Chapter 373, Florida Statutes, Section 373.4592

Everglades restoration, https://www.nap.edu/catalog/25198/ progress-toward-restoring-the-everglades-the-seventhbiennial-review-2018

\section{Acknowledgments}

The authors are indebted to the personnel of both state and federal agencies who provided their time and advice in the preparation of this handbook. We acknowledge Carol Fountain and Susan Gildersleeve at the University of Florida for their assistance in editing this handbook. We also acknowledge funding received for updating this publication from the James S. and Dorothy F. Wershow Agricultural Law Endowment. 